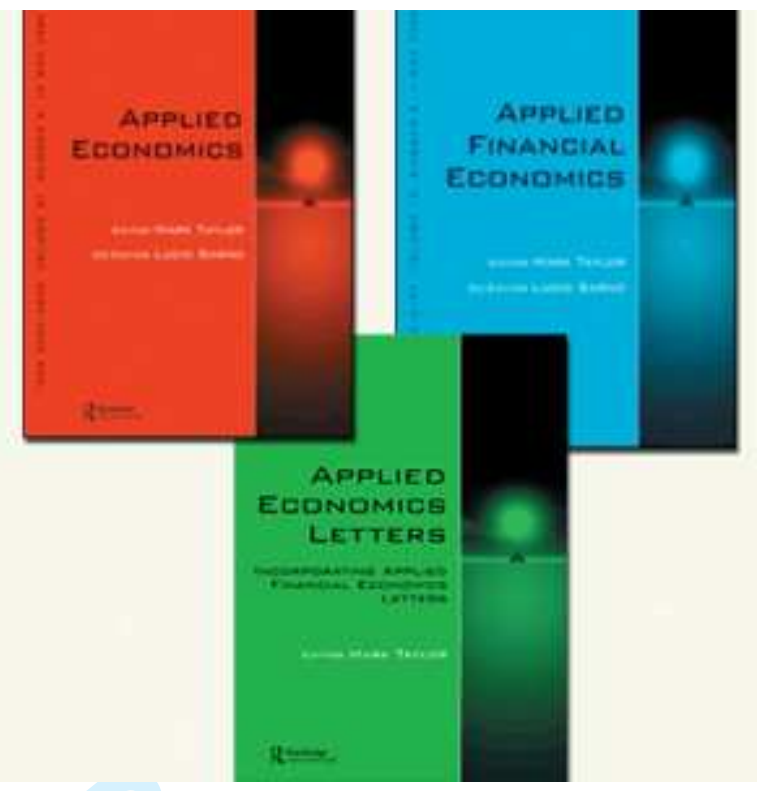

\title{
SPANISH STOCK MARKET SENSITIVITY TO REAL INTEREST AND INFLATION RATES. AN EXTENSION OF THE STONE TWO-FACTOR MODEL WITH FACTORS OF THE FAMA AND FRENCH THREE-FACTOR MODEL
}

\begin{tabular}{|c|c|}
\hline Journal: & Applied Economics \\
\hline Manuscript ID: & APE-06-0168.R1 \\
\hline Journal Selection: & Applied Economics \\
\hline $\begin{array}{l}\text { Date Submitted by the } \\
\text { Author: }\end{array}$ & 24-Aug-2006 \\
\hline Complete List of Authors: & $\begin{array}{l}\text { Jareño, Francisco; Universidad de Castilla-La Mancha, Financial } \\
\text { Economics }\end{array}$ \\
\hline JEL Code: & $\begin{array}{l}\text { E31 - Price Level|Inflation|Deflation < E3 - Prices, Business } \\
\text { Fluctuations, and Cycles < E - Macroeconomics and Monetary } \\
\text { Economics, L29 - Other < L2 - Firm Objectives, Organization, and } \\
\text { Behavior < L - Industrial Organization, G12 - Asset Pricing < G1 - } \\
\text { General Financial Markets < G - Financial Economics }\end{array}$ \\
\hline Keywords: & $\begin{array}{l}\text { Real interest and inflation sensitivity, Stock return, Determinants of } \\
\text { interest sensitivity }\end{array}$ \\
\hline
\end{tabular}




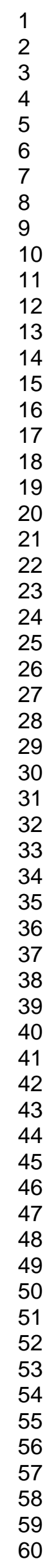

\section{SCHOLARONE ${ }^{m}$ \\ Manuscripts}

7

25

26

27

29

30

31

33

34

35

36

37

38

41

42

43

45

46

47

48

49

51

52

53

54

55

57

58

59

60 


\title{
SPANISH STOCK MARKET SENSITIVITY TO REAL INTEREST AND INFLATION RATES. AN EXTENSION OF THE STONE TWO-FACTOR MODEL WITH FACTORS OF THE FAMA AND FRENCH THREE-FACTOR MODEL
}

(This draft: August 2006)

\author{
Francisco Jareño (Francisco.jareno@uclm.es)* \\ Universidad de Castilla-La Mancha
}

Running Title: Spanish Stock Market Sensitivity to Real Interest and Inflation Rates

\begin{abstract}
This study is focussed on estimating the real interest and inflation sensitivity in Spanish market, proposing an extension of the Stone (1974) two-factor model and controlling for size and growth of the companies (Fama and French (1993) three-factor model), because of its importance in the stock sensitivity shown by previous literature. I also study the classical explanatory factors of the stock sensitivity: leverage and liquidity level of the firms. The Spanish stock response is similar to the response in other markets, and the "size" is higher than "growth" effect.
\end{abstract}

Keywords: Real interest and inflation sensitivity; Stock return; Determinants of interest sensitivity

JEL Classification: E31, G12, G3, L2

* Departamento de Análisis Económico y Finanzas

Universidad de Castilla-La Mancha

Facultad de CC Económicas y Empresariales de Albacete, Plaza de la Universidad, 1, 02071 - Albacete (Spain)

Francisco.Jareno@uclm.es

Tel: +34967599200

Fax: +34967599220 


\section{Introduction}

Some previous studies have analyzed the stock sensitivity to unanticipated movements in nominal interest rates (or real interest and inflation rates), and they have also studied the main explanatory determinants from individual characteristics of the companies. These determinants show that it would be interesting to include the "size" and the "growth expectations" of the companies in the sensitivity estimation model (Lilti and Montagner, 1998, Cornell, 2000, Barnard and Villiers, 2003, Leledakis et al., 2003, Aray and Gardeazabal, 2004, Chelley-Steeley and Steeley, 2005, and Jareño, 2006).

In this paper, the main contribution is the proposal of a hybrid model between Stone (1974) two-factor and Fama and French (1993) three-factor model to estimate the Spanish stock sensitivity to real interest and inflation rate movements, controlling for the size and growth opportunities of the company. Later I study the main explanatory factors of both real interest and inflation sensitivities (Leibowitz et al., 1989, and Tessaromatis, 2003).

\section{Literature review}

A lot of previous literature has emphasized the significance of reaching a measurement of the interest rate sensitivity of equities. The body of this literature is based on the Stone (1974) two-factor model (Lynge and Zumwalt, 1980, Sweeney and Warga, 1986, O’Neal, 1998, Fraser et al., 2002, Bartram, 2002, Soto et al., 2005, and Staikouras, 2005), focussing mainly on the financial institutions.

In the Spanish case, Ferrer is remarkable for having written some studies about empirical estimates of duration and interest rate sensitivity in general (Soto et al., 2005, Ferrer et al., 1999, Ferrer and Matallín, 2004, and Ferrer et al., 2005).

Nevertheless, since 1992, Fama and French have outlined the importance of three factors (an overall market factor and factors related to firm size and book-tomarket equity) in explaining security returns (L'Her et al., 2004, and Faff, 2004).

In this context, this study contributes to the literature proposing an extension of the Stone (1974) model with "size" and "growth" factors from the Fama and French (1993) model.

Besides, this decision is backed up by some recent literature (Black, 2000, Brennan et al., 2004, Aretz et al., 2005, and Petkova, 2006) which concludes that SMB 
("size" factor) and HML ("growth" factor) are good for predicting macroeconomic variables, specifically economy expectations and default risk premium.

\subsection{The Stone (1974) two-factor model}

Empirical evidence about interest rate sensitivity normally has been based on the extension of the CAPM (Capital Asset Pricing Model), which adds an interest rate change factor. This two-factor model was proposed by Stone (1974), who extends the single-factor market model to a two-factor model to "better" explain the stochastic process that generates security returns (e.g. Arango et al., 2002):

$$
r_{j t}=\alpha_{j}+\beta_{j} \cdot r_{m t}+\gamma_{j} \cdot \Delta i_{t}^{u}+\varepsilon_{j t}
$$

where $r_{j t}$ is the stock $j$ return in month $t, \beta_{j k}$ shows the stock sensitivity to factor $k$ movements, $r_{m t}$ is the return on the market portfolio, $\Delta i_{t}^{u}$ represents (unexpected) changes in nominal interest rates and, finally, $\varepsilon_{t}$ is the error term.

\subsection{The Fama and French (1993) three-factor model}

Fama and French (1993) propose a three-factor model which captures most of the stock return variations. According to this model, the three factors are: the market return, and the return on a "size" and "growth" factor portfolio. The both portfolio returns capture the risk factors related with the stock size and growth opportunities. Fama and French (1993), FF from now on, suggest the following expression (e.g. Faff, 2004):

$$
r_{j t}=\alpha_{j}+\beta_{j m} \cdot r_{m t}+\beta_{j S M B} \cdot S M B_{t}+\beta_{j H M L} \cdot H M L_{t}+\varepsilon_{t}
$$

where $r_{j t}$ is the stock $j$ return in month $t, \beta_{j k}$ shows the stock sensitivity to factor $k$

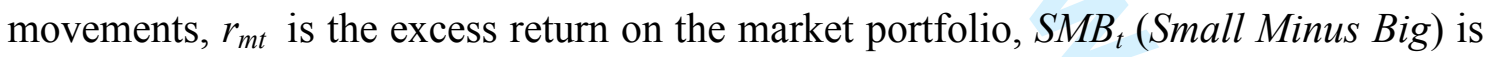
the return on the size factor portfolio, $H_{M L}$ (High Minus Low) denotes the return on the growth factor portfolio and, finally, $\varepsilon_{t}$ is the error term.

\subsection{Proposal of a hybrid model between Stone (1974) two-factor and Fama and French (1993) three-factor model}

In this paper, I suggest an extension of the Stone (1974) model using factors of the Fama and French (1993) model. In this proposal, apart from the market and size and growth portfolio return, I add variations in the real interest and expected inflation rate. 
Thus, I will be able to prove if the size and growth opportunities of the companies are significant factors to explain the stock returns, such as previous research has demonstrated (Kadiyala, 2000, and Tessaromatis, 2003).

Finally, the proposed model is shown now:

$$
r_{j t}=\alpha_{j}+\beta_{j m} \cdot r_{m t}^{*}+\beta_{j r} \cdot \Delta r_{t}^{*}+\beta_{j \pi} \cdot \Delta E_{t}\left(\pi_{t, t+12}\right)+\beta_{j S M B} \cdot S M B_{t}+\beta_{j H M L} \cdot H M L_{t}+\varepsilon_{j t}
$$

where $r_{j t}$ is the stock $j$ return in month $t, \beta_{j k}$ shows the stock sensitivity to factor $k$ movements, $r_{m t}^{*}$ is the return on the market portfolio (orthogonalized) ${ }^{1}, \Delta r_{t}{ }^{*}$ represents changes in real interest rates (orthogonalized), $\Delta E_{t}\left(\pi_{t, t+12}\right)$ shows shocks in expected inflation rate, $S M B_{t}\left(\right.$ Small Minus Big) is the return on the size factor portfolio, $H M L_{t}$ (High Minus Low) denotes the return on the growth factor portfolio and, finally, $\varepsilon_{t}$ is the error term.

\section{Data and methology}

This research uses a sample of monthly data of Spanish consumer price index (IPC) released by "Instituto Nacional de Estadística" (INE) from February 1993 to December 2004.

To remove the seasonal component of the IPC series, I use a year-to year inflation rate. Thus, I smooth the IPC series without disturbances and I work out each piece of data like this:

$$
\pi_{t}=\frac{I P C_{t}-I P C_{t-12}}{I P C_{t-12}}
$$

being $I P C_{t}$ the consumer price index at time $t$, obtaining an unseasoned inflation rate $\left(\pi_{t}\right)$ each month.

In the same sample period, I rely on daily stock quotations in the Spanish Stock Exchange (SIBE). ${ }^{2}$ I consider the total of the companies which have quoted during some period in the sample, to avoid a possible survival bias in case of taking into account only the companies which cover the whole sample.

Moreover, I incorporate to the analysis individual companies of which I have plenty of information about price data (around 90 monthly observations, that is, at least

\footnotetext{
${ }^{1}$ To avoid the possible existence of multicollinearity between the explanatory variables, it is usually used some orthogonalization procedure. Following Lynge and Zumwalt (1980), Flannery and James (1984), Sweeney (1998) and Fraser et al. (2002), the market return has been regressed on a constant and the series of real interest and inflation rates using OLS (ordinary least squares) estimation. Thus, the effect of each factor is isolated and the movement that remains is captured by the residuals.

${ }^{2}$ I adjust stock prices by splits.
} 
a $60 \%$ of the whole sample). The sample is made up of 74 firms. In the table 1 , I show the number of companies included and the sector belongs to ( $4 \%$ to the sector $6,10 \%$ to the sector 1 and 4, $20 \%$ to the sector 3 y, finally, $28 \%$ to the sector 2 and 5 ).

\section{[INSERT TABLE 1]}

I work out stock returns with closing price of the last day of the current month and the previous month: ${ }^{3}$

$$
r_{j t}=\frac{P_{t}-P_{t-1}+D_{t}}{P_{t-1}}
$$

being $r_{j t}$ the return of the month $t$, which is obtained from closing price of the last day of the previous month $\left(P_{t-1}\right)$ and the current month $\left(P_{t}\right)$, taking into account the current dividend $\left(D_{t}\right)$.

\subsection{Market returns}

With regard to the market return, Spanish financial literature traditionally has used some index sufficiently representative of our market. Thus, measures traditionally used as proxies of the market portfolio have been IBEX-35 and IGBM index.

In this research, I choose IGBM index, because of adding the evolution of a high number of securities, so this index seems to be a better approximation of the market evolution. I work out market returns such as stock returns -see expression [5]-.

\subsection{Unexpected changes in nominal interest rates}

An important point in this analysis is concerned to the choice of the adequate interest rate to employ. Most of the literature uses long-term interest rates because they incorporate the future expectations of economic agents and they determine the corporate borrowing cost, so they have a lot of influence on the investment decisions of firms and, finally, they affect the value of companies. Besides, I have used the total variations in long-term interest rates to capture unanticipated changes in interest rates (Sweeney and Warga, 1986, Kane and Unal, 1988, Bartram, 2002 and Oertmann et al., 2000).

Some researchers use alternative procedures such as forecast error of the ARIMA process to model the unexpected interest rate (Flannery and James, 1984). Mishkin (1982) approach the unanticipated changes in interest rates with the spread between spot interest rate of the three month treasury bills in period $t$ and forward rate

\footnotetext{
${ }^{3}$ I take into account that the last day of the month for which I have information about prices must not be previous than seven days before to the last calendar day of the month.
} 
of the three month treasury bills in yield curve during period $t-1$. On the other hand, Fendel (2005) develop a Taylor rule expression for the interest rate dynamics and he concludes that interest rates can be sufficiently explained by expected variations in inflation and output plus an additional unobservable factor.

Benink and Wolff (2000) use survey data on the US federal funds rate. Weekly surveys generate market expectations, which are confronted with the realized value of the federal funds rate for the same period (period of execution of surveys). Likewise, authors can work out unexpected movement in federal funds rate for the mentioned period that is going to be used in the estimation of the interest risk sensitivity in an indices model.

Survey forecasts of interest rates have been studied in the literature (Froot, 1989) and they are an interesting alternative for the use of ARIMA model forecasts, because they are intrinsically "forward looking". Moreover, some studies indicate that standard time-invariant time series models simply cannot be viewed as adequate representations of relatively complex interest rate processes. Froot (1989) uses an extensive data set covering the period 1969-86 and he finds evidence that expected future short term rates under-react to current short term rate changes. He could not reject the hypothesis that the market's expectation of future short term rates is rational. With regard to long term interest rates, he finds expectational biases in the survey data. The behaviour of the expectational errors suggests that expected future rates under-react to short term interest rate changes. Froot (1989) rejects the expectations theory of interest rate, so he can state that each approach, time series and surveys, have their own advantages and drawbacks.

In this study I use first differences of the long-term interest rates as a good approach of the unexpected changes in the nominal interest rates. The body of literature, mainly in the US market, has relied on 1,3, 5 and 10-year Treasury bond yields and three-month Treasury bill yields as interest rate proxy variable.

The returns of the Treasury securities in different maturities are usually used as the risk-free interest rate proxies. It is supposed that these securities have not default risk.

In the Spanish case, I have decided to use returns series of the one-year Treasury debt securities. This risk-free interest rate approximation allows me to obtain changes in real interest rates, $\Delta r_{t}$, as the difference between variations in nominal interest rates, $\Delta i_{t}$, and year-to year inflation rate, $\Delta E_{t}\left(\pi_{t, t+12}\right)$ : 


$$
\Delta i_{t}=\Delta r_{t}+\Delta E_{t}\left(\pi_{t, t+12}\right)
$$

\subsection{Expected inflation rate}

Firstly, I want to emphasize that it is possible to distinguish several methodologies for measuring the expected component of inflation rate. On the one hand, a large body of literature uses simple time series models, ARIMA models, to forecast or estimate the expected inflation component. It is supposed that current total inflation rate $\left(\pi_{t}\right)$ can be broken down into the sum of its expected $\left(\pi_{t}^{e}\right)$ and unexpected $\left(\pi_{t}^{u}\right)$ component. The expected component is estimated using ARIMA models assuming that this component depends on own past of the series. Besides, the unexpected component is obtained as the difference between the observed total inflation rate and expected component. I can stress the following authors in this current of opinion: Pearce and Roley (1988), Schwert (1981), Joyce and Read (2002), Fraser et al. (2002), Mestel and Gurgul (2003), and Browne and Doran (2005).

On the other hand, a group of researchers uses periodical surveys of forecasts, such as MMS (International Money Market Services) -weekly- or Thomson Financial, as suitable proxies of the expected inflation rate. Some examples are Berk (1999), Flannery and Protopapadakis (2002), Andersen et al. (2002) and Adams et al. (2004). In Spain there are some companies dedicated to publish certain situation surveys, but I lack of this kind of Spanish information to use it as a proxy of the expected inflation rate.

Schwert (1981), Asikoglu and Ercan (1992) and Moosa and Kwiecien (1999) use short-term interest rates as predictors of inflation rate, but according to Alonso et al. (2000) in Spain interest rates do not increase to a great extent the explanatory capability of the own past of the prices.

Another current of opinion relies on certain expressions which depend on multiple variables for estimating the inflation rate, such as the growth of the money supply, labour cost, crude oil price or, for example, the growth of the industrial production ( $\mathrm{Hu}$ and Willett, 2000 and Boyd et al., 2005). Other authors use VAR models (autoregressive vectors) to obtain the inflation rate, as Hagmann and Lenz (2004) and Anari and Kolari (2001), and even other methods such as the simple Kalman filter (Lee, 1992, and Cassola and Luís, 2003) or the Hodrick - Prescott filter (Kramer, 1998, and Pérez de Gracia and Cuñado, 2001). Some recent studies (Sack, 2000, Alonso 
et al., 2001, Tessaromatis, 2003, and Gapen, 2003) have used government inflationindexed bonds, but they are not available in Spain.

Finally, authors such as Ariño and Canela (2002) exhibit the naïve model as an easy way to estimate the expected inflation rate and, consequently, the unexpected component. This model assumes that the better forecast at time $t$ is the last known data $(t-1$, generally).

This research uses the most popular approximation in the body of literature based on forecast errors of ARIMA processes (time series models) to estimate the expected inflation rate. Likewise, Joyce and Read (2002) and Browne and Doran (2005) observe similar results using ARIMA and other alternative procedures. ${ }^{4}$

Thus, I start from Box-Jenkins identification-estimation methodology of ARIMA (autoregressive integrated moving average model) time series models. From matching the ACF (autocorrelation function) and PACF (partial autocorrelation function) with the theoretical patterns of known models, I realize that ARMA $(1,0)$ process provides the best possible results between alternative autoregressive moving average processes with residuals as white noise. So, I use the ARMA $(1,0)$ process to predict the month-tomonth inflation rate, that is, I suppose shortsightedness exptectations (Leiser and Drori, $2005)::^{5}$

$$
E_{t}\left(\pi_{t, t+12}\right)=\pi_{t-12, t}
$$

A standard test of unbiasedness of inflation considered measure involves to regressing the total inflation rate (actual inflation rate in the economy) on the proposed measure: ${ }^{6}$

$$
\pi_{t-12, t}=\alpha+\beta \cdot E_{t-12}\left(\pi_{t-12, t}\right)+u_{t}
$$

If these estimations are unbiased forecasts of the actual inflation rate, then it is expected that $\alpha=0$ and $\beta=1$ and $u_{t}$ will be serially uncorrelated. The estimation is reported in Table 2. The regressions demonstrates that the joint hypothesis $(\alpha=0$ and $\beta$ $=1$ ) cannot be rejected. Besides, $\alpha$ is not significantly different from zero and $\beta$ is significantly close to one.

\footnotetext{
${ }^{4}$ These models, in contrast to structural models, do not need additional information for doing forecasts, because they use lagged inflation values. I have repeated this procedure until the end of sample, with onestep-ahead forecast, obtaining the expected component of inflation rate.

${ }^{5}$ Unit root tests confirm that inflation rate is a I(1) series, so this result is consistent with shortsightedness expectations.

${ }^{6}$ I have conducted an historical unbiasedness test, because of the limited yearly sample.
} 


\section{[INSERT TABLE 2]}

So, I can affirm that this measure of expected inflation rate can be considered as an unbiased estimator of ex - post inflation rate, because I can accept the joint hypothesis $(\alpha=0$ and $\beta=1)$.

\section{4. "Size" and "growth" factors}

To obtain the SMB and HML portfolio returns, which are based on SMB and HML from FF, I have proceeded as follows. With regard to the "size" portfolio, firstly I have ranked companies on the size ratio (natural logarithm of the market capitalization). Using the median size, I have split the sample into two samples groups and I have named "Small" $(S)$, companies with the lowest size, and "Big" $(B)$, companies with the highest size. Later, I have broken stock sample into three book-to-market equity groups based on the breakpoints for the bottom $30 \%$ ("Low", $L$ ), middle $40 \%$ ("Medium", $M$ ) and top $30 \%$ ("High", $H$ ) of the ranked values of book-to-market ratio for stocks.

Then I construct six portfolios $(S / L, S / M, S / H, B / L, B / M, B / H)$ from the intersections of the five previous groups. The returns of the size portfolio, $S M B$, are created as the difference between the monthly average return of "Small" $(S / L, S / M$ y $S / H)$ and "Big" $(B / L, B / M$ y $B / H)$ portfolios (Small Minus Big). Moreover, the monthly average returns of the growth portfolio, HML (High Minus Low), are created as the difference between the monthly average return of the companies with the highest growth opportunities $(S / H$ y $B / H)$ and the companies with the lowest growth ratio $(S / L$ y $B / L){ }^{7}$

\section{[INSERT FIGURE 1]}

\section{Estimation and results of the hybrid model between Stone (1974) and Fama and French (1993) model}

The estimation of the model [3] has been executed using the "seemingly unrelated regression", SUR (Zellner, 1962), taking into account heteroskedasticity and the possible contemporaneous correlation in the error terms across equations.

Table 3 shows the percentage of companies that present a significant response to variations of each factor, the main statistics of this response and, finally, the sectorial distribution.

\section{[INSERT TABLE 3]}

\footnotetext{
${ }^{7}$ Unit root tests confirm the stationarity of the variables included in the proposed model.
} 
The majority of the 74 analyzed companies exhibit a positive and significant sensitivity to variations in the market return $(95.95 \%$, at the $1 \%$ significance level). The average significant sensitivity is around 0.7368, swinging between 0.1481 (Banco de Galicia, S.A.) and 1.3359 (Tele Pizza S.A.). Sectorially, "Financial and Real State Services" is the sector with the lowest sensitivity to changes in the market return (0.6190), whereas "Technology and Telecommunications" is the sector that presents the higher market sensitivity (1.1390).

As regards the movements of the real interest rates, the results confirm the previous literature, that is, a negative sensitivity. In the Spanish case, a high number of companies are significantly sensitive to this factor (43.24\% approximately). The average sensitivity is around -6.43 , fluctuating between these values: +5.95 (Faes Farma, S.A.) and -18.06 (Avanzit, S.A.). The sector with the highest number of companies with significant sensitivity $(71.43 \%)$ is sector 1 , meanwhile sector 3 shows the lowest percentage of companies sensitive to movements in real interest rates $(33.33$ $\%$ ). If I focus on the average sectorial sensitivity, sector 6 exhibits a high response to changes in real interest rates (value close to -11.81). Contrarily, sectors 1 and 3 are the lesser sensitive sectors (-5.61 y -5.32 , respectively).

As Tessaromatis (2003), a high percentage of the companies do not respond significantly to changes in expected inflation rate factor. "Banco Santander Central Hispano, S.A." and "Banco Bilbao Vizcaya Argentaria, S.A." show a not significant response, so these companies, that are ones of the leader firms in "Financial and real state services" sector, seem to have a strong "flow-through capability" (Jareño, 2005). This dominance position in a sector was stressed in previous research as a key factor about the company capability to transfer inflationist shocks to prices (Kadiyala, 2000). At sectorial level, "Oil and Energy" sector presents the lowest significant sensitivity to expected inflation rate movements $(-3.06),{ }^{8}$ and sector 3 , the highest one (-6.14).

The size factor, in contrast to some preceding literature, seems to be a key factor for explaining the movements of the stock returns (Leledakis et al., 2003), reaching results quite similar to Cornell (2000) and Barnard and Villiers (2003). About a $50 \%$ of the companies show a positive and significant coefficient, so this result suggests that an important size effect exists. Besides, the smallest companies present a higher return than the biggest companies, being the average value about 0.7185 . Sectorially, "Oil and

\footnotetext{
${ }^{8}$ This result is consistent with a previous study (Jareño, 2005), in which "Oil and Energy" shows a high flow-through capability.
} 
Energy" sector is the sole sector with a negative size factor coefficient (-0.16). In the rest of sectors, "Technology and Telecommunications" is characterized by exhibiting a high amount coefficient (1.56), although sectors 2 and 4 have a higher percentage of companies with significant coefficients $(75 \%)$.

Finally, the growth factor shows a lower percentage of companies with statistical significance (36\%). Moreover, the sign of the growth factor is unclear (positive, $24 \%$ and negative, $12 \%$ ). According to the percentage of companies and also the statistical significance level, I can affirm that growth effect is slightly smaller than size effect. Focussing on the sectorial analysis, sectors show negative and significant coefficients (except sectors 1 and 5 that present positive coefficient), remarking the high sensitivity showed by "Technology and Telecommunications" (-0.75).

According to Cornell (2000) and Barnard and Villiers (2003), the size effect is stronger than book-to-market effect, the same result reached with Spanish data. It is possible that small companies have option characteristics not related with characteristics captured by book-to-market ratio. The interest rates sensitivity of small companies could evidence an explanation for their strange higher returns.

\section{Explanatory determinants of the real interest and inflation sensitivity in the hybrid model between Stone (1974) and Fama and French (1993) model}

To complete the analysis of the real interest and inflation sensitivity of Spanish companies, I study the possible explanatory factors: the leverage level and the liquidity of the company, because size and growth factors are incorporated in the model proposed in this research. Also I take into account the fact that one company belongs to one or another sector:

$$
\hat{\beta}_{j}=\delta_{0}+\delta_{1} \cdot \text { leverage }+\delta_{2} \cdot \text { liquidity }+\sum_{k=1}^{6} \delta_{k+2} \cdot D_{k}+\varepsilon_{j}
$$

where $\beta_{j}$ shows the estimated sensitivity to changes in real interest and expected inflation rates, leverage represents the yearly average financial leverage level of each company, liquidity reflects the yearly average capability of each company to generate cash flows, and $D_{k}$ denotes a dummy variable that takes value 1 when company $j$ belongs to sector $k$ and zero otherwise.

Due to the estimated coefficients of real interest and inflation sensitivity have mainly negative sign, I consider the estimated sensitivity with the sign changed to make easier its interpretation. Moreover, as usual in relating literature, the model of the 
expression [9], has been estimated using OLS techniques with standard errors corrected for autocorrelation and heteroskedasticity using the White procedure.

\section{[INSERT TABLE 4]}

As we can see in the estimation of the real interest and inflation sensitivity with the proposed model, in case of real interest rate sensitivity (Panel A, Table 4), I find the leverage level of the company as possible explanatory factor. This factor shows positive coefficient, but its amount is very small (0.06-0.08), so the higher the leverage level of the company, the higher the sensitivity to variations in real interest rates. I emphasize that this result is robust in all the tests (Bichsel and Blum, 2004).

Nevertheless, as regards the inflation sensitivity (Panel B, Table 4), the leverage level proposed factor appears with a lower statistical significance level for explaining the exposure of the stock returns to changes in expected inflation rate. Also, the explanatory power of the factors is lower in the inflation sensitivity $(3 \%)$ than in case of real interest sensitivity $(1.46 \%)$.

According to these results, I can state that the financial leverage ratio of the companies is the key factor to measure the interest rate exposure of the companies. I evidence that companies with high leverage rate have to face up to a higher debt cost, mainly in period of growing interest rates. This fact affects negatively to company earnings, that is, companies are vulnerable to interest risk to a large extent.

\section{Summary and concluding remarks}

Numerous studies have focussed on analysing the sensitivity of stock returns to unexpected variations in nominal interest rates, demonstrating a negative and significant relation between stock returns and these unanticipated movements of nominal interest rates: Sweeney and Warga (1986), O’ Neal (1998), Fraser et al. (2002), Oertmann et al. (2000), Kwan (2000), Hevert et al. (1998 a and b) and Tessaromatis (2003).

Some of this research has checked the importance of factors such as the growth opportunities of the companies or their size. So, I have improved my analysis with the study of the hybrid model between Stone (1974) two-factor and Fama and French (1993) three-factor model, the main contribution of this paper. In this framework, I have incorporated as explanatory variables of the stock returns not only changes in real interest and expected inflation rates but also other two factors proposed by Fama and French (1993), the returns on "size" and "growth" portfolio. 
As regards the real interest rate sensitivity, the sectorial returns are affected significant and negatively by real interest rate movements. Again, returns do not vary significantly to changes in expected inflation rate, but I find a positive and significant relation between stock returns and size portfolio returns $(50 \%$ of the companies approximately). Likewise, these results are in line with other authors such as Cornell (2000).

To conclude, I emphasize my contribution made to Spanish market, because it is the first time that real interest sensitivity is separated from inflation sensitivity using an extension of Stone (1974) model with size and growth factors of Fama and French (1993) model. I reach results quite similar to other international research. Finally, I have tried to find some factors related with own characteristics of individual firms to explain these sensitivities, stressing the main role of the company leverage level.

\section{Acknowledgments}

I am very grateful to my colleagues of the Financial Economics Section for their contributions, mainly to my $\mathrm{PhD}$ thesis director, Eliseo Navarro, and codirector, Antonio Díaz, and Gonzalo Rubio. Besides I acknowledge the financial support provided by Junta de Comunidades de Castilla-La Mancha grant PAI-05-074. 


\section{References}

ADAMS, G., MCQUEEN, G. AND R. WOOD (2004), 'The Effects of Inflation News on High Frequency Stock Returns', Journal of Business, Vol. 77, N 3, pp. 547574.

ALONSO-SÁNCHEZ, F., AYUSO-HUERTAS, J. AND J. MARTÍNEZ-PAGÉS (2000), 'El Contenido Informativo de los Tipos de Interés sobre la Tasa de Inflación Española', Investigaciones Económicas, Vol. XXIV, No 2, pp. 455-471

ALONSO, F. BLANCO, R. AND A. RÍO (2001), 'Estimating inflation expectations using French government inflation-indexed bonds', Banco de España - Servicio de Estudios. Documento de trabajo $N^{o} 0111$.

ANARI, A. AND J. KOLARI (2001), 'Stock Prices and Inflation', The Journal of Financial Research, Vol. XXIV, № 4, pp. 587-602.

ANDERSEN, T. G., BOLLERSLEV, T., DIEBOLD, X. AND C. VEGA (2003), 'Micro Effects of Macro Announcements: Real-Time Price Discovery in Foreign Exchange', The American Economic Review, Vol. 93, No 1, pp. 38-62.

ARANGO, L. E., GONZÁlEZ, A. AND C. E. POSADA (2002), 'Returns and the interest rate: a non-linear relationship in the Bogota' stock market', Applied Financial Economics, Vol. 12, No 11-1, pp. 835-842.

ARAY, H. AND GARDEAZABAL, J. (2004), 'Macroeconomic Announcements and Stock Returns: The Case of Spain', Working paper.

ARETZ, K., BARTRAM, S. M. AND POPE, P. F. (2005), 'Macroeconomic Risks and the Fama and French / Carhart Model', EFA 2005 Moscow Meeting.

ARIÑO, M. A. AND M. A. CANELA (2002), 'Evolución de la inflación en España?', IESE, Centro Internacional de Investigación Financiera (CIIF), Documento de investigación $N^{\circ} 446$.

ASIKOGLU, Y. AND M. R. ERCAN (1992), 'Inflation Flow-Through and Stock Prices', Journal of Portfolio Management, Vol 18, No 3, pp. 63-68.

BARNARD, I. AND J. DE VILLIERS (2003), 'Size effects, growth opportunities and the sensitivity of share prices to interest rates', Working Paper.

BARTRAM, S. M. (2002), 'The Interest Rate Exposure of Nonfinancial Corporations', European Finance Review, Vol. 6, Nº 1, pp. 101-125.

BENINK, H. AND C. WOLFF (2000), 'Survey Data and the Interest Rate Sensitivity of US Bank Stock Returns', Economic Notes, Vol. 29, No 2-2000, pp. 201-213.

BERK, J. M. (1999), 'Measuring inflation expectations: a survey data approach', Applied Economics, Vol. 31, № 11-1, pp. 1467-1480. 
BICHSEL, R. AND J. BLUM (2004), 'The relationship between risk and capital in Swiss commercial banks: a panel study', Applied Financial Economics, Vol. 14, $\mathrm{N}^{\mathrm{o}} 8-1$, pp. 591-597

BLACK, A. J. (2000), 'Expected returns and business conditions: a commentary on Fama and French', Applied Financial Economics, Vol. 10, No 4-1, pp. 389-400.

BOYD, J. H., HU, J. AND R. JAGANNATHAN (2005), 'The Stock Market's Reaction to Unemployement News: Why Bad News is Usually Good for Stocks', The Journal of Finance, Vol. 60, No 2, pp. 649-672.

BRENNAN, M. J., WANG, A. W. AND XIA, Y. (2004), 'Estimation and test of a simple model of intertemporal capital asset pricing', The Journal of Finance, Vol. 59, $\mathrm{N}^{\mathrm{o}} 4$, pp. 1743-1775.

BROWNE, F. AND D. DORAN (2005), 'Do equity index industry groups improve forecasts of inflation and production? A US analysis', Applied Economics, Vol. $37, \mathrm{~N}^{\mathrm{o}} 15-20$, pp. 1801-1812.

CASSOLA, N. AND J. B. LUÍS (2003), 'A two-factor model of the German term structure of interest rates', Applied Financial Economics, Vol. 13, No 11, pp. 783-806.

CHELLEY-STEELEY, P. L. AND J. M. STEELEY (2005), 'The leverage effect in the UK stock market', Applied Financial Economics, Vol. 15, No 6-15, pp. 409-423.

CORNELL, B. (2000), 'Equity Duration, Growth Options, and Asset Pricing', Journal of Portfolio Management, Spring2000, Vol. 26, N 3, pp.105-111.

FAFF, R. (2004), 'A simple test of the Fama and French model using daily data: Australian evidence', Applied Financial Economics, Vol. 14, № 2-15, pp. 83-92.

FAMA, E. F. AND K. R. FRENCH (1993), 'Common Risk Factors in the Returns on Stocks and Bonds', Journal of Financial Economics, Vol. 33, pp. 3-56.

FENDEL, R. (2005), 'An affine three-factor model of the German term structure of interest rates with macroeconomic content', Applied Financial Economics Letters, Vol. 1, № 3, pp. 151-156.

FERRER LAPEÑA, R., GONZÁLEZ BAIXAILU, C. AND SOTO PACHECO, G. M. (2005), 'Oportunidades de crecimiento empresarial y riesgo de interés en el mercado bursátil español', Revista Española de Financiación y Contabilidad, Vol. XXXIV, No 126, pp. 595-612.

FERRER LAPEÑA, R. Y MATALLÍN SÁEZ, J. C. (2004), 'Exposición al riesgo de tipo de interés de los fondos de inversión de renta variable: evidencia en el caso español', Revista Española de Financiación y Contabilidad, Vol. XXXIII, N ${ }^{\circ}$ 122, pp. 637-668.

FERRER, R., SANTOMÁ, J. Y SEBASTIÁN, A (1999), 'El riesgo de interés en el mercado español de acciones. Una aproximación sectorial', Revista Española de Financiación y Contabilidad, Vol. XXVIII, N 98, pp. 43-75. 
FLANNERY, M. J. AND C. JAMES (1984), 'The effect of interest rate changes on the common stock returns of financial institutions', The Journal of Finance, Vol. 39, pp. 1141-1153.

FLANNERY, M. J. AND A. A. PROTOPAPADAKIS (2002), 'Macroeconomic Factors Do Influence Aggregate Stock Returns', The Review of Financial Studies, Vol. 15, No 3, pp. 751-782.

FRASER, D., MADURA, J. AND R. A. WEIGAND (2002), 'Sources of Bank Interest Rate Risk', The Financial Review, Vol. 37, No 3, pp. 351-368.

FROOT, K. (1989), 'New Hope for the Expectations Hypothesis of the Term Structure of Interest Rates', The Journal of Finance, Vol. 44, pp. 283-305.

GAPEN, M. T. (2003), 'Seasonal indexation bias in US Treasury Inflation-indexed Securities', Applied Financial Economics, Vol. 13, No 7, pp. 509-516.

HAGMANN, M. AND C. LENZ (2004), 'Real Asset Returns and Components of Inflation: A Structural VAR Analysis', Working Paper, FAME Research Paper No. 118.

HEVERT, K. T., MCLAUGHLIN, R. M. AND R. A. TAGGART (1998 a), 'Growth Options and Equity Duration', Journal of Portfolio Management, Vol. 25, $\mathrm{N}^{\mathrm{o}} 1$, Fall 1998. pp. 43-50.

HEVERT, K. T., MCLAUGHLIN, R. M. AND R. A. TAGGART (1998 b), 'Interest Rates, Inflation and the Value of Growth Options', The Quarterly Review of Economics and Finance, Vol. 38, Special Issue, pp. 599-613.

HU, X. AND T. D. WILLETT (2000), 'The variability of inflation and real stock returns', Applied Financial Economics, Vol. 10, pp. 655-665.

JAREÑO, F. (2005), 'Flow-through capability: the Spanish case', Journal of Asset Management, Vol. 6, № 3, pp. 191-205.

JAREÑO, F. (2006), 'Sensibilidad de los rendimientos sectoriales a tipos de interés reales e inflación', Investigaciones Económicas, Forthcoming.

JOYCE, M. A. S. AND V. READ (2002), 'Asset price reactions to RPI announcements', Applied Financial Economics, Vol. 12, pp. 253-270.

KADIYALA, P. (2000), 'The Relation Between the Magnitude of Growth Opportunities and the Duration of Equity', The Journal of Financial Research, Vol. XXIII, No 3, Fall 2000, pp. 285-310.

KANE, E. J. AND H. UNAL (1988), 'Change in market assessments of depositinstitution riskiness', Journal of Financial Services Research, Vol. 1, pp. 207229.

KRAMER, J. (1998), 'Determinants of the expected real long-term interest rates in the G7-countries', Applied Economics, Vol. 30, No 2-1, pp. 279-285.

KWAN, S. (2000), 'Three Questions about New Economy Stocks', Federal Reserve Bank of San Francisco Economic Letter, 2000, № 12. 
LEE, B. (1992), 'Causal Relations Among Stock Returns, Interest Rates, Real Activity, and Inflation', The Journal of Finance, Vol. XLVII, No 4, September. pp. 15911603.

LEIBOWITZ, M. L., SORENSEN, E. H., ARNOTT, R. D AND N. HANSON (1989), 'A total Differential Approach to Equity Duration', Financial Analysts Journal, Vol. 45, No 5, September-October, pp. 30-37.

LELEDAKIS, G., DAVIDSON, I. AND G. KARATHANASSIS (2003), 'Crosssectional estimation of stock returns in small markets: The case of the Athens Stock Exchange', Applied Financial Economics, Vol. 13, № 6, pp. 413-426

LILTI, J-J AND H. R-L MONTAGNER (1998), 'Beta, size and returns: a study on the French Stock Exchange', Applied Financial Economics, Vol. 8, No 1-1, pp. 1320.

LYNGE, M. J., JR AND J. K. ZUMWALT (1980), 'An empirical study of the interest rate sensitivity of commercial bank returns. A multi-index approach', Journal of Financial and Quantitative Analysis, Vol. 15, pp. 731-742.

L'HER, J-F., MASMOUDI, T. AND SURET, J-M. (2004), 'Evidence to support the four-factor pricing model from the Canadian stock market', Journal of International Financial Markets, Institutions \& Money, Vol. 14, № 4, pp. 313328.

MESTEL, R. AND H. GURGUL (2003), 'ARIMA Modeling of Event Induced Stock Price Reactions in Austria', Central European Journal of Operations Research, Vol. 11, No 4, December. pp. 317-334.

MISHKIN, F. S. (1982), 'Monetary Policy and Short-Term Interest Rates: An Efficient Markets-Rational Expectations Approach', The Journal of Finance, Vol. 37, No 1, pp. 63-72.

MOOSA, I. A. AND J. KWIECIEN (1999), 'The nominal interest rate as a predictor of inflation: a re-examination of the underlying model', Applied Financial Economics, Vol. 9, № 4-1, pp. 337-341.

O'NEAL, E.S. (1998), 'Why electric utility stocks are sensitive to interest rates', The Financial Review, Vol. 33, No 1, pp. 147-162.

OERTMANN, P., RENDU, C. AND H. ZIMMERMANN (2000), 'Interest Rate Risk of European Financial Corporations', European Financial Management, Vol. 6, No 4, 2000, pp. 459-478.

PEARCE, D. K. AND V. ROLEY (1988), 'Firm Characteristics, Unanticipated Inflation, and Stock Returns', The Journal of Finance, Vol. XLIII, N ${ }^{\circ}$. pp. 965-981

PÉREZ DE GRACIA, F. AND J. CUÑADO (2001), 'Inflación y rendimientos bursátiles en el caso español, 1941-1999', Estudios sobre la Economía Española, FEDEA, No 65 . 
PETKOVA, R. (2006), 'Do the Fama-and French factors proxy for innovations in state variables?', The Journal of Finance, Vol. 61, № 2, pp. 581-612.

SACK, B. (2000), 'Deriving Inflation Expectations from Nominal and Inflation-indexed Treasury Bills', Journal of Business, Vol. 60, No 4, pp. 473-489.

SCHWERT, G. W. (1981), 'The Adjustment of Stock Prices to Information about Inflation', The Journal of Finance, $\mathrm{N}^{\mathrm{o}} 36, \mathrm{~N}^{\mathrm{o}}$ 1, pp. 15-29.

SOTO, G. M., FERRER, R. AND GONZÁLEZ, C. (2004), 'Determinants of Interest Rate Exposure of Spanish Non-financial Firms', European Review of Economics and Finance, Vol. 4, № 3, pp. 55-71.

STAIKOURAS, S. K. (2005), 'Equity returns of financial institutions and the pricing of interest rate risk', Applied Financial Economics, Vol. 15, No 7-1, pp. 499-508.

STONE, B. K. (1974), 'Systematic Interest-Rate Risk in a Two-Index Model of Returns', Journal of Financial and Quantitative Analysis, Vol. 9 (November 1974), pp. 709-721.

SWEENEY, R. J. AND A. D. WARGA (1986), 'The pricing of interest rate risk: evidence from the stock market', The Journal of Finance, Vol. 41, $\mathrm{N}^{\mathrm{o}}$ 2, pp. 393-410.

TESSAROMATIS, N. (2003), 'Stock Market Sensitivity to Interest Rates and Inflation', Working Paper, EFMA 2003 Meeting in Helsinki.

ZELLNER, A. (1962), 'An Efficient Method of Estimating Seemingly Unrelated Regressions, and Tests for Aggregation Bias', Journal of the American Statistical Association, Vol. 57, pp. 348-368. 
Table 1

Companies included in the analysis and the sector belongs to

\begin{tabular}{|c|c|c|c|}
\hline Sector name & Subsectors & $\begin{array}{l}\text { Number of } \\
\text { firms }\end{array}$ & $\begin{array}{c}\% \\
\text { aprox. }\end{array}$ \\
\hline Sector 1: Oil and Energy & $\begin{array}{l}\text { 1.1.: Oil } \\
\text { 1.2.: Electricity and Gas } \\
\text { 1.3.: Water and Others }\end{array}$ & 7 & $10 \%$ \\
\hline $\begin{array}{l}\text { Sector 2: Basic Materials, Industry } \\
\text { and Construction }\end{array}$ & $\begin{array}{l}\text { 2.1.: Minerals, Metals and Transformation } \\
\text { 2.2.: Manufacture and assembly of capital assets } \\
\text { 2.3.: Construction } \\
\text { 2.4.: Construction Materials } \\
\text { 2.5.: Chemistry Industry } \\
\text { 2.6.: Engineering and Others } \\
\text { 2.7.: Aerospace }\end{array}$ & 20 & $28 \%$ \\
\hline Sector 3: Consumer Goods & $\begin{array}{l}\text { 3.1.: Food and Drinks } \\
\text { 3.2.: Textile, Clothes and Footwear } \\
\text { 3.3.: Paper and Graphic Arts } \\
\text { 3.4.: Car } \\
\text { 3.5.: Pharmaceutical Products and Biotechnology } \\
\text { 3.6.: Other Consumer Goods }\end{array}$ & 15 & $20 \%$ \\
\hline Sector 4: Consumer Services & $\begin{array}{l}\text { 4.1.: Tourism and Hotel and Catering Business } \\
\text { 4.2.: Retail Trade } \\
\text { 4.3.: Media and Advertising } \\
\text { 4.4.: Transport and Distribution } \\
\text { 4.5.: Motorways and Car Parks } \\
\text { 4.6.: Other Services }\end{array}$ & 8 & $10 \%$ \\
\hline $\begin{array}{l}\text { Sector 5: Financial and Real State } \\
\text { Services }\end{array}$ & $\begin{array}{l}\text { 5.1.: Bank } \\
\text { 5.2.: Insurance } \\
\text { 5.3.: Portfolio and Holding } \\
\text { 5.4.: SICAV } \\
\text { 5.5.: Real State Agencies and Others }\end{array}$ & 21 & $28 \%$ \\
\hline $\begin{aligned} \text { Sector 6: Technology and } \\
\\
\text { Telecommunications }\end{aligned}$ & $\begin{array}{l}\text { 6.1.: Telecommunications and Others } \\
\text { 6.2.: Electronics and Software }\end{array}$ & 3 & $4 \%$ \\
\hline Total market & & 74 & $100 \%$ \\
\hline
\end{tabular}




\section{Table 2}

\section{Unbiasedness test}

OLS regression with the yearly data (from Feb. 1964 to Jan. 2005):

$$
\pi_{t-12, t}=\alpha+\beta \cdot E_{t-12}\left(\pi_{t-12, t}\right)+u_{t}
$$

where $\pi_{t-12, t}$ shows the total inflation rate, $E_{t-12}\left(\pi_{t-12, t}\right)$ the expected inflation rate and $u_{t}$ the error term \# Wald test allows to check the joint hypothesis: $\alpha=0$ and $\beta=1$ (F-statistic value is showed)

\begin{tabular}{|c|c|c|c|c|}
\hline & Intercept & Beta & $\operatorname{Adj} R^{2}$ & Wald test \# \\
\hline Nä̈ve Model & $\begin{array}{c}0.008656 \\
(1.171342)\end{array}$ & $\begin{array}{l}0.891894^{\mathrm{c}} \\
(12.13410)\end{array}$ & 0.781025 & 1.086506 \\
\hline
\end{tabular}


Table 3

Sensitivity of stock returns to variations in real interest and expected inflation rates, market return and size and growth portfolios

$r_{j t}$ represents stock returns at time $t$ for each company/sector $j, r_{m t}{ }^{*}$ is the orthogonalized return on the market portfolio, $\Delta r_{t}{ }^{*}$ represents changes in real interest rates (orthogonalized), $\Delta E_{t}\left(\pi_{t, t+12}\right)$ shows movements in expected

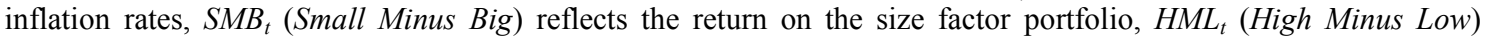
denotes the return on the growth factor portfolio and, finally, $\varepsilon_{t}$ is the error term. The sample extends from Feb. 1993 to Dec. 2004 and the following regression has been estimated using SUR methodology. $t$-statistics in parentheses ${ }^{a} \mathrm{p}$ $<0.10,{ }^{\mathrm{b}} \mathrm{p}<0.05,{ }^{\mathrm{c}} \mathrm{p}<0.01$

$r_{j t}=\alpha_{j}+\beta_{j m} \cdot r_{m t}^{*}+\beta_{j r} \cdot \Delta r_{t}^{*}+\beta_{j \pi} \cdot \Delta E_{t}\left(\pi_{t, t+12}\right)+\beta_{j S M B} \cdot S M B_{t}+\beta_{j H M L} \cdot H M L_{t}+\varepsilon_{j t}$

PANEL A: Percentage of companies with significant exposure

\begin{tabular}{|c|c|c|c|c|}
\hline$r_{m t}{ }^{*}$ & Signif. $1 \%$ & Signif. $5 \%$ & Signific. $10 \%$ & No signif. \\
\hline Signif. Sens. & $71(95.95 \%)$ & $73(98.65 \%)$ & $74(100 \%)$ & \\
\hline Posit. Sens. & $71(95.95 \%)$ & $73(98.65 \%)$ & $74(100 \%)$ & 0 \\
\hline Negat. Sens. & 0 & 0 & 0 & 0 \\
\hline T. firms $=74$ & 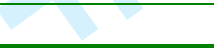 & & $74(100 \%)$ & 0 \\
\hline$\Delta r_{t}{ }^{*}$ & Signif. $1 \%$ & Signif. $5 \%$ & Signific. $10 \%$ & No signif. \\
\hline Signif. Sens. & $16(21.62 \%)$ & $25(33.78 \%)$ & $32(43.24 \%)$ & \\
\hline Posit. Sens. & 0 & 0 & $1(1.35 \%)$ & $15(20.27 \%)$ \\
\hline Negat. Sens. & $16(21.62 \%)$ & $25(33.78 \%)$ & $31(41.89 \%)$ & $27(36.49 \%)$ \\
\hline T. firms $=74$ & & & $32(43.24 \%)$ & $42(56.76 \%)$ \\
\hline$\Delta E_{t}\left(\pi_{t, t+12}\right)$ & Signif. $1 \%$ & Signif. $5 \%$ & Signific. $10 \%$ & No signif. \\
\hline Signif. Sens. & $1(1.35 \%)$ & $4(5.41 \%)$ & $8(10.81 \%)$ & \\
\hline Posit. Sens. & 0 & 0 & 0 & $20(27.03 \%)$ \\
\hline Negat. Sens. & $1(1.35 \%)$ & $4(5.41 \%)$ & $8(10.81 \%)$ & $46(62.16 \%)$ \\
\hline T. firms $=74$ & & & $8(10.81 \%)$ & $66(89.19 \%)$ \\
\hline$S M B_{t}$ & Signif. $1 \%$ & Signif. $5 \%$ & Signific. $10 \%$ & No signif. \\
\hline Signif. Sens. & $33(44.59 \%)$ & $39(52.70 \%)$ & $43(58.11 \%)$ & \\
\hline Posit. Sens. & $32(43.24 \%)$ & $33(44.59 \%)$ & $37(50 \%)$ & $20(27.03 \%)$ \\
\hline Negat. Sens. & $1(1.35 \%)$ & $6(8.11 \%)$ & $6(8.11 \%)$ & $11(14.86 \%)$ \\
\hline T. firms $=74$ & & & $43(58.11 \%)$ & $31(41.89 \%)$ \\
\hline$H M L_{t}$ & Signif. $1 \%$ & Signif. $5 \%$ & Signific. $10 \%$ & No signif. \\
\hline Signif. Sens. & $15(20.27 \%)$ & $23(31.08 \%)$ & $27(36.49 \%)$ & \\
\hline Posit. Sens. & $8(10.81 \%)$ & $15(20.27 \%)$ & $18(24.32 \%)$ & $20(27.03 \%)$ \\
\hline Negat. Sens. & $7(9.46 \%)$ & $8(10.81 \%)$ & $9(12.16 \%)$ & $27(36.49 \%)$ \\
\hline T. firms $=74$ & & & $27(36.49 \%)$ & $47(63.51 \%)$ \\
\hline
\end{tabular}

PANEL B: Descriptive statistics of significant estimated sensitivity

\begin{tabular}{|c|c|c|c|c|c|}
\hline & $r_{m t}{ }^{*}$ & $\Delta r_{t}^{*}$ & $\Delta E_{t}\left(\pi_{t, t+12}\right)$ & $S M B_{t}$ & $H M L_{t}$ \\
\hline Mean & 0.7369 & -6.4293 & -4.8366 & 0.7185 & 0.0153 \\
\hline Maximum & 1.3359 & 5.9538 & -3.0628 & 1.9411 & 0.9648 \\
\hline Minimum & 0.1481 & -18.0580 & -6.6586 & -0.5246 & -1.7262 \\
\hline Std. Dev. & 0.2729 & 3.8605 & 1.4450 & 0.6179 & 0.8063 \\
\hline Observations & 74 & 32 & 8 & 43 & 27 \\
\hline
\end{tabular}


PANEL C: Significant sectorial sensitivity

\begin{tabular}{|c|c|c|}
\hline$r_{m t}{ }^{*}$ & Firms with Signif. Sensit. & Average Signif. Sensit. \\
\hline Sector 1: Oil and Energy & $7 / 7(100 \%)$ & 0.7861 \\
\hline $\begin{array}{c}\text { Sector 2: Basic Mat., Industry } \\
\text { and Construction }\end{array}$ & $20 / 20(100 \%)$ & 0.8227 \\
\hline Sector 3: Consumer Goods & $15 / 15(100 \%)$ & 0.6879 \\
\hline Sector 4: Consumer Services & $8 / 8(100 \%)$ & 0.7295 \\
\hline $\begin{array}{c}\text { Sector 5: Financial and Real } \\
\text { State Services }\end{array}$ & $21 / 21(100 \%)$ & 0.6190 \\
\hline $\begin{array}{l}\text { Sector 6: Technology and } \\
\text { Telecommunications }\end{array}$ & $3 / 3(100 \%)$ & 1.1390 \\
\hline Total market & $74 / 74(100 \%)$ & 0.7369 \\
\hline$\Delta r_{t}^{*}$ & Firms with Signif. Sensit. & Average Signif. Sensit. \\
\hline Sector 1: Oil and Energy & $5 / 7(71.43 \%)$ & -5.6090 \\
\hline $\begin{array}{c}\text { Sector 2: Basic Mat., Industry } \\
\text { and Construction }\end{array}$ & $8 / 20(40 \%)$ & -7.9712 \\
\hline Sector 3: Consumer Goods & $5 / 15(33.33 \%)$ & -5.3240 \\
\hline Sector 4: Consumer Services & $3 / 8(37.50 \%)$ & -6.4917 \\
\hline $\begin{array}{c}\text { Sector 5: Financial and Real } \\
\text { State Services }\end{array}$ & $9 / 21(42.86 \%)$ & -4.9111 \\
\hline $\begin{array}{c}\text { Sector 6: Technology and } \\
\text { Telecommunications }\end{array}$ & $2 / 3(66.67 \%)$ & -11.8135 \\
\hline Total market & $32 / 74(43.24 \%)$ & -6.4293 \\
\hline$\Delta E_{t}\left(\pi_{t, t+12}\right)$ & Firms with Signif. Sensit. & Average Signif. Sensit. \\
\hline Sector 1: Oil and Energy & $1 / 7(14.29 \%)$ & -3.0628 \\
\hline $\begin{array}{c}\text { Sector 2: Basic Mat., Industry } \\
\text { and Construction }\end{array}$ & $2 / 20(10 \%)$ & -5.8885 \\
\hline Sector 3: Consumer Goods & $1 / 15(6.67 \%)$ & -6.1430 \\
\hline Sector 4: Consumer Services & $1 / 8(12.5 \%)$ & -3.0926 \\
\hline $\begin{array}{c}\text { Sector 5: Financial and Real } \\
\text { State Services }\end{array}$ & $3 / 21(14.29 \%)$ & -4.8725 \\
\hline $\begin{array}{l}\text { Sector 6: Technology and } \\
\text { Telecommunications }\end{array}$ & $0 / 3(0 \%)$ & 0 \\
\hline Total market & $8 / 74(10.81 \%)$ & -4.8366 \\
\hline$S M B_{t}$ & Firms with Signif. Sensit. & Average Signif. Sensit. \\
\hline Sector 1: Oil and Energy & $4 / 7(57.14 \%)$ & -0.1624 \\
\hline $\begin{array}{c}\text { Sector 2: Basic Mat., Industry } \\
\text { and Construction }\end{array}$ & $15 / 20(75 \%)$ & 0.9137 \\
\hline Sector 3: Consumer Goods & $11 / 15(73.33 \%)$ & 0.7878 \\
\hline Sector 4: Consumer Services & $6 / 8(75 \%)$ & 0.8467 \\
\hline $\begin{array}{c}\text { Sector 5: Financial and Real } \\
\text { State Services }\end{array}$ & $6 / 21(28.57 \%)$ & 0.4219 \\
\hline $\begin{array}{l}\text { Sector 6: Technology and } \\
\text { Telecommunications }\end{array}$ & $1 / 3(33.33 \%)$ & 1.5608 \\
\hline Total market & $43 / 74(58.11 \%)$ & 0.7185 \\
\hline$H M L_{t}$ & Firms with Signif. Sensit. & Average Signif. Sensit. \\
\hline Sector 1: Oil and Energy & $5 / 7(71.43 \%)$ & 0.3823 \\
\hline $\begin{array}{c}\text { Sector 2: Basic Mat., Industry } \\
\text { and Construction }\end{array}$ & $5 / 20(25 \%)$ & -0.1174 \\
\hline Sector 3: Consumer Goods & $8 / 15(53.33 \%)$ & -0.0213 \\
\hline Sector 4: Consumer Services & $6 / 8(75 \%)$ & -0.2161 \\
\hline $\begin{array}{c}\text { Sector 5: Financial and Real } \\
\text { State Services }\end{array}$ & $2 / 21(9.52 \%)$ & 0.6547 \\
\hline $\begin{array}{c}\text { Sector 6: Technology and } \\
\text { Telecommunications }\end{array}$ & $1 / 3(33.33 \%)$ & -0.7533 \\
\hline Total market & $27 / 74(36.49 \%)$ & 0.0153 \\
\hline
\end{tabular}




\section{Table 4}

\section{Determinants of real interest and inflation rate sensitivity}

$\beta_{j}$ shows the estimated sensitivity to real interest and expected inflation rate changes, leverage represents the yearly average financial leverage level of each company, liquidity reflects the yearly average capability of each company to generate cash flows and $D_{k}$ denotes a dummy variable that takes value 1 when company $j$ belongs to sector $k$ and zero otherwise. The sample includes 74 observations. The following regression has been estimated using OLS techniques with standard errors corrected for autocorrelation and heteroskedasticity using the White procedure. $t$-statistics in parentheses ${ }^{\mathrm{a}} \mathrm{p}<0.10,{ }^{\mathrm{b}} \mathrm{p}<0.05,{ }^{\mathrm{c}} \mathrm{p}<0.01$

$\hat{\beta}_{j}=\delta_{0}+\delta_{1} \cdot$ leverage $+\delta_{2} \cdot$ liquidity $+\sum_{k=1}^{6} \delta_{k+2} \cdot D_{k}+\varepsilon_{j}$

Panel A

\begin{tabular}{lcccc}
\hline Leverage & $\Delta \boldsymbol{r}_{\boldsymbol{t}}{ }^{*}$ & $\Delta \boldsymbol{r}_{\boldsymbol{t}}{ }^{*}$ & $\Delta \boldsymbol{r}_{\boldsymbol{t}}{ }^{*}$ & $\Delta \boldsymbol{r}_{\boldsymbol{t}}{ }^{*}$ \\
\hline Liquidity & $\begin{array}{c}\text { a } \\
(1.7826)\end{array}$ & Not included & $\begin{array}{c}0.0801^{\text {a }} \\
(1.7693)\end{array}$ & $\begin{array}{c}0.0629 \\
(1.5105)\end{array}$ \\
\hline $\boldsymbol{D 1}$ & Not included & $\begin{array}{c}-0.2383 \\
(-0.4061)\end{array}$ & $\begin{array}{c}-0.2383 \\
(-0.5250)\end{array}$ & $\begin{array}{c}0.1165 \\
(0.1538)\end{array}$ \\
\hline $\boldsymbol{D} \mathbf{D}$ & Not included & Not included & Not included & $\begin{array}{c}2.6485 \\
(1.6160)\end{array}$ \\
\hline $\boldsymbol{D 3}$ & Not included & Not included & Not included & $\begin{array}{c}2.3972 \\
(1.5357)\end{array}$ \\
\hline $\boldsymbol{D 4}$ & Not included & Not included & Not included & Not included \\
\hline $\boldsymbol{D 5}$ & Not included & Not included & Not included & $\begin{array}{c}1.3465 \\
(0.7404)\end{array}$ \\
\hline $\boldsymbol{D} 6$ & Not included & Not included & Not included & $\begin{array}{c}0.5200 \\
(0.1615)\end{array}$ \\
\hline $\mathrm{R}^{2}$ ajust. & Not included & Not included & Not included & $\begin{array}{c}4.3742 \\
(0.8133)\end{array}$ \\
\hline
\end{tabular}

Panel B

\begin{tabular}{|c|c|c|c|c|}
\hline & $\Delta E_{t}\left(\pi_{t, t+12}\right)$ & $\Delta E_{t}\left(\pi_{t, t+12}\right)$ & $\Delta E_{t}\left(\pi_{t, t+12}\right)$ & $\Delta E_{t}\left(\pi_{t, t+12}\right)$ \\
\hline Leverage & $\begin{array}{c}0.0385 \\
(1.5832)\end{array}$ & Not included & $\begin{array}{c}0.0385 \\
(1.5627)\end{array}$ & $\begin{array}{c}0.0276 \\
(1.0321)\end{array}$ \\
\hline Liquidity & Not included & $\begin{array}{c}-0.2324 \\
(-0.8158)\end{array}$ & $\begin{array}{c}-0.2324 \\
(-1.0141)\end{array}$ & $\begin{array}{c}-0.2495 \\
(-0.8206)\end{array}$ \\
\hline$D 1$ & Not included & Not included & Not included & $\begin{array}{c}1.4935 \\
(1.5688)\end{array}$ \\
\hline$D 2$ & Not included & Not included & Not included & $\begin{array}{c}1.5206 \\
(1.4735)\end{array}$ \\
\hline D3 & Not included & Not included & Not included & Not included \\
\hline D4 & Not included & Not included & Not included & $\begin{array}{c}0.9577 \\
(0.7463)\end{array}$ \\
\hline D5 & Not included & Not included & Not included & $\begin{array}{c}1.6726 \\
(1.6502)\end{array}$ \\
\hline D6 & Not included & Not included & Not included & $\begin{array}{c}2.3546 \\
(1.1162)\end{array}$ \\
\hline $\mathrm{R}^{2}$ ajust. & 0.0245 & -0.0101 & 0.0146 & -0.0055 \\
\hline
\end{tabular}




\section{Figure 1}

Evolution of the variables included in the analysis

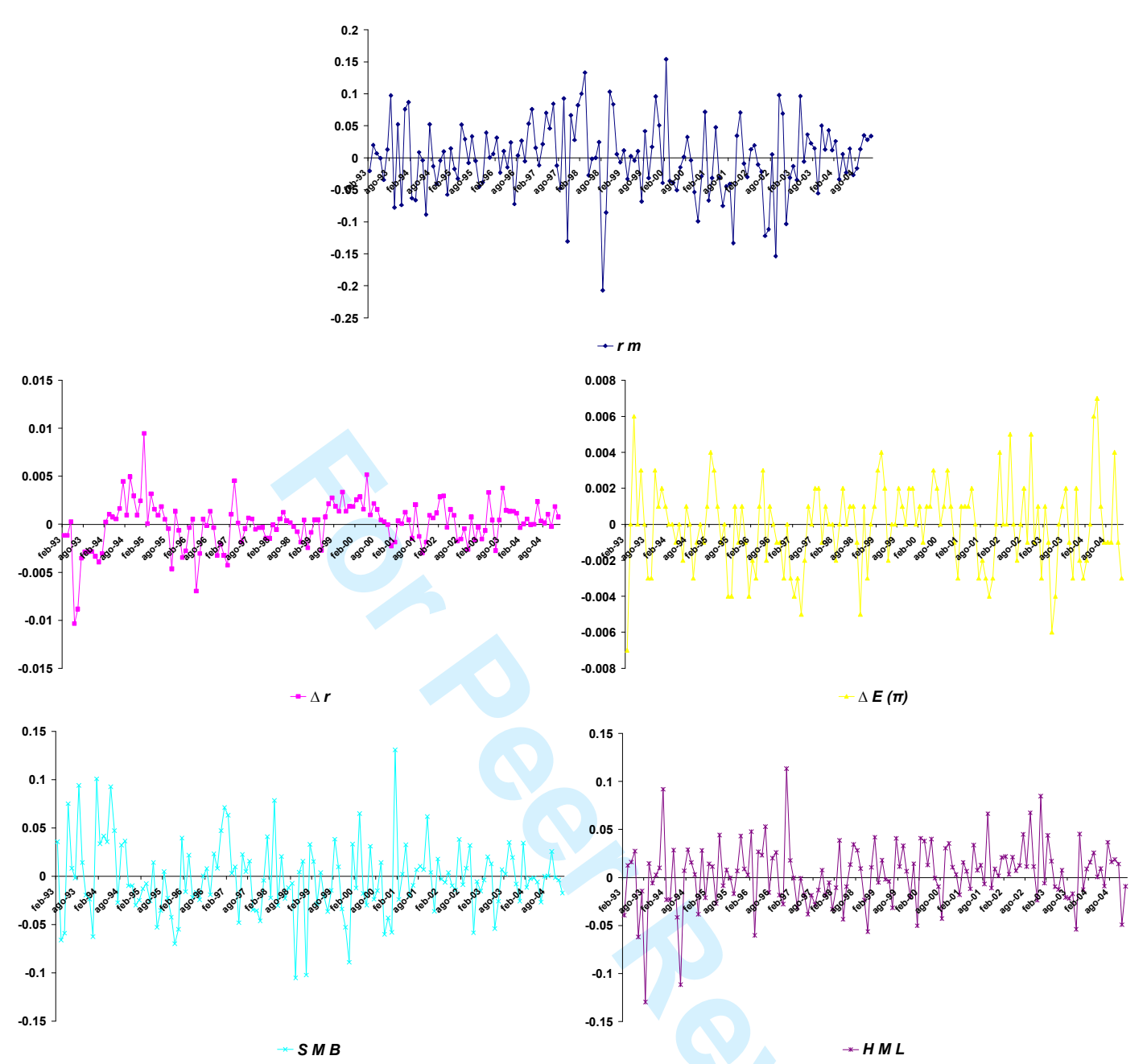

